\title{
A STUDY ON THE EFFECTIVENESS OF CLOMIPHENE CITRATE IN COMPARISON TO GnRH ANTAGONIST IN PREVENTING LH SURGE AMONG PATIENTS UNDERGOING OVULATION INDUCTION IN IVF-ICSI
}

\author{
Shiuan Yee Tan, ${ }^{1}$ Salleha Khalid, ${ }^{2}$ Mohamad Azrai Abu, ${ }^{3}$ \\ Abdul Kadir Abdul Karim, ${ }^{3}$ Mohd Hashim Omar ${ }^{3}$ \\ ${ }^{1}$ Seberang Jaya Hospital, Ministry of Health, Malaysia \\ ${ }^{2}$ Faculty medicine and health sciences, University Sains Islam Malaysia (USIM), Malaysia \\ ${ }^{3}$ UKM Reproductive centre, Department of obstetrics and gynecology, \\ University Kebangsaan Malaysia, Malaysia
}

Primljen/Received 06. 07. 2018. god.

Abstract: Objective: To determine the efficacy of clomiphene citrate (CC) in preventing luteinizing hormone (LH) surge without adding gonadotropin releasing hormone $(\mathrm{GnRH})$ antagonist or $\mathrm{GnRH}$ agonist in stimulated first fresh intracytoplasmic sperm injection cycle by evaluating the outcome of oocytes and embryo quality. Design: Registry cohort study. Settings: Fertility Clinic Registry at Hospital University Kebangsaan Malaysia. Patients: A total of 235 fresh stimulated ICSI cycle for patients aged 18-40 years old using clomiphene citrate plus gonadotropin $(\mathrm{n}=117)$ and $\mathrm{GnRH}$ antagonist plus gonadotropin $(\mathrm{n}=118)$ were studied. Intervention: Comparing two different ovarian stimulation protocol. Main outcome measure(s): Social economical demographic, ovarian stimulation response and laboratory outcome. Fertilization rate as our primary outcome and our secondary outcome were oocyte retrieval rate, mature oocyte rate and top quality embryo rate. Result(s):There were no difference in the demographic and hormonal characteristic of the study groups. The primary outcome of fertilization rate has significant difference with $\mathrm{p}$ value of $0.003 ; 73.2 \%$ for $\mathrm{CC}$ group and $64.2 \%$ for $\mathrm{GnRH}$ antagonist group. The secondary outcome of OR rate $(78.4 \% \pm 17.6 \% \mathrm{VS}$ $80.3 \% \pm 13.4 \%, p=0.368)$, mature oocyte rate $(85.2 \%$ \pm 19.0 VS $81.7 \% \pm 16.7 \%, \mathrm{p}=0.130)$ and top quality embryo rate $(79.4 \% \pm 24.2 \%$ VS $74.9 \% \pm 22.9 \%, p=$ 0.178 ) were comparable between both groups. There were significant difference between the endometrial thickness on the day of trigger and OHSS risk among
Prihvaćen/Accepted 01. 08. 2018. god.

both groups ( $8.5 \mathrm{~mm} \pm 1.0 \mathrm{~mm}$ VS $9.4 \mathrm{~mm} \pm 1.1 \mathrm{~mm}, \mathrm{p}$ $<0.001$ and $12.8 \%$ VS $44.1 \%$ respectively).

Discussion: Minimal stimulation protocol with CC and gonadotropin may be the answer to many infertile couples in need of IVF and yet having financial situation deterring them in attempting IVF treatment. GnRH antagonist could be safely replaced by $\mathrm{CC}$ by extending to 10 days as this protocol gives better primary outcome and comparable secondary outcomes with less OHSS. $\mathrm{CC}$ is recognized to induce thinning of endometrial lining and thus, may impair embryo implantation. However, with advancement of the vitrification system and higher success rate in frozen-thaw embryo transfer worldwide provides an excellent solution for this issue.

Key words: Clomiphene citrate, minimal stimulation, GnRH antagonist, premature LH surge, low cost IVF.

\section{INTRODUCTION}

Controlled ovarian stimulation (COS) is an important component in IVF in order to yield optimum number of oocytes with the aim of achieving the best pregnancy outcome (1). There are various protocol that were created to assist patient to conceive without compromising the outcome, such as cycle cancellation due to premature ovulation secondary to LH surge and unwanted complication such as ovarian hyperstimulation syndrome (OHSS). This maximum ovarian stimulation has been challenged by International Society for Mild Approaches in Assisted Reproduction (ISMAAR) in which minimal stimulation provides a simple, safe, cheap and less injec- 
tion and stimulation days for patients undergoing ICSI (1, $2,3)$. It has become a popular for patients with good prognosis, poor responders and women of advanced age as an alternative to conventional protocol $(1,4,5)$.

Premature LH surge during ovarian stimulation has become the main concern for clinicians (6) as it would lead to poor quality of oocyte, poor fertilization and cycle cancellation. The incidence of LH surge was reported to be as high as $15-30 \%$ (6) leading to cycle cancellation which is unacceptable to the patients and clinicians. This lead to the role of adding GnRH antagonist or GnRH agonist protocol in IVF to prevent LH surge. Agonist protocol has become less popular as it required more injection and prolonged stimulation which was considered unfriendly to the patients. More than $60 \%$ of our ICSI patients undergoing ovarian stimulation using antagonist protocol and the rest were by natural or long agonist protocol for the past 10 years. This explained the reason of using GnRH antagonist protocol as a control in our study.

Clomiphene citrate (anti-estrogen) is used commonly in minimal stimulation protocol as an ovarian stimulation agent. It has a role acting as anti-estrogen blocking the negative feedback to hypothalamus pituitary axis in returns stimulating FSH to produce more follicle (7). Co-administration of CC and gonadotrophin is to reduce the dose requirement of gonadotrophin particularly for patient that prefer less injection. Many authors suggested the need of adding GnRH antagonist in preventing $\mathrm{LH}$ surge if $\mathrm{CC}$ was used in ovulation stimulation protocol (8) as it has showed to have higher cancellation rate due to LH surge. Extended use of CC till the day of trigger has been advocated recently as $\mathrm{CC}$ has its anti-estrogenic effect to block spontaneous LH surge replacing GnRH antagonist or GnRH agonist agents. Al-Inany (9) has proved the efficacy of CC from their research published in 2010 but in IUI patients. It was then further studied by Bhandari S (7) on IVF patients that the fertilization rate using this protocol was as high as $76.1 \%$ and it was a viable option without additional use of antagonists. But the study design was not a comparison study to show the effectiveness of CC to replace GnRH antagonist agent. Many recent studies showed acceptable cancellation rate for this protocol using $\mathrm{CC}(8.57 \%)$ which is lower than the standard rate (7). Using CC with gonadotrophin without adding $\mathrm{GnRH}$ antagonist was promising $(8,9,10)$ as it was claimed to be user friendly with less injection, less gonadotrophin requirement and less cost burden to patients.

\section{AIM}

$\mathrm{CC}$ has been used since last few decades in our center as ovarian stimulation agents in ICSI cycle. One of the advantage of using CC in ICSI is that it could reduce the usage and total cost of gonadotropin as we are movingly slowly towards minimal stimulation protocol. Recently we have extended it's used to 10 days and we hypothesize that $\mathrm{CC}$ is as effective as $\mathrm{GnRH}$ antagonist in preventing LH surge by looking at the laboratory outcome of the oocyte and embryo. Fertilization rate is our primary outcome and our secondary outcome were oocyte retrieval (OR) rate, mature oocyte rate and top quality embryo rate. Poor oocyte and embryo quality and less number of fertilized embryo is best reflecting the evidence of $\mathrm{LH}$ surge without the need of checking LH level in blood or urine. We do not study on pregnancy outcome as there are various confounding factors affecting the outcome particularly the causes if infertility.

\section{MATERIALS AND METHODS}

\section{Patient selection}

This was a retrospective study evaluating the efficacy of clomiphene citrate in comparison with the conventional GnRH antagonist protocol in preventing $\mathrm{LH}$ surge among patients aged 18-40 years old undergoing ICSI in our MAC clinic at University Kebangsaan Malaysia (partially funded hospital) between January 2016 and December 2017. The data was retrieved via medical records kept at MAC Fertility Clinic Registry. The exclusion criteria were 1) poor ovarian reserve (either FSH $>10 \mathrm{iu} / \mathrm{L}$ or $\mathrm{AMH}<5.4 \mathrm{pmol} / \mathrm{L}$ ); 2) azoospermia patients; 3) Large ovarian cyst $>3 \mathrm{~cm}$, 4) previous failed IVF cycle; 5) BMI $>30.0$.

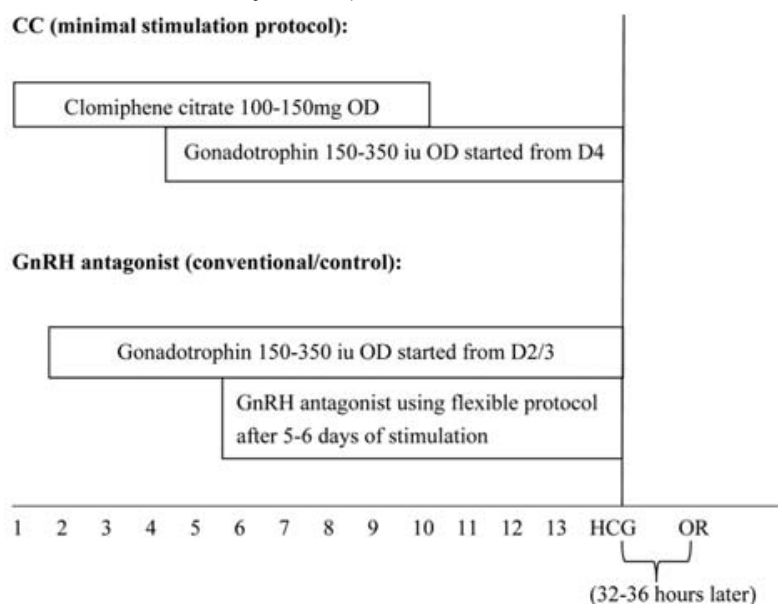

Figure 1. Ovarian stimulation protocol

The women were stimulated using mild stimulation protocol with CC 50mg two tablet a day commenced since day one of menses. Gonadotropin with recombinant FSH (Gonal-F, Puregon) or hMG (Menopur) were added from day four of menstrual cycle onwards. The starting dose of gonadotropin was dependent on the age and causes of infertility. CC would be extended till day 10 of menstrual cycle. Transvaginal scan would be performed on day 8 or day 10 and scan would be repeated every 2 to 3 days according to the 
ovarian response. Gonadotropin would be continue beyond day 10 till the leading follicle reaching $\geq 18 \mathrm{~mm}$. Final oocyte maturation was achieved by human chorionic gonadotropin (HCG) with either subcutaneous pregnyl 10,000 iu or Ovidrel $0.25 \mathrm{mg}$.

For conventional controlled ovarian stimulation using GnRH antagonist protocol, patients would be stimulated with recombinant FSH (Gonal-F, Puregon) or hMG (Menopur) from day 2 or day 3 of cycle. Transvaginal scan would be performed on day 8 of cycle and repeated every 2 to 3 days depending on the response. GnRH antagonist agent (Cetrotide or orgalutran $0.25 \mathrm{mg}$ ) was added when the leading follicle reaching $14 \mathrm{~mm}$ (flexible protocol) in diameter and continued till triggering day with single dose HCG as mentioned earlier.

TVOR was performed 32-36 hours following HCG administration under sedation at day care theatre. Patient would be excluded if unexpected poor ovarian response or premature ruptured of follicle during the TVOR day. Serum E2, P4 and LH were not routinely performed during the ovarian stimulation in our centre.

\section{ICSI}

We performed ICSI for all the cases as these were partially funded program to ensure higher fertilization rate than conventional IVF. Embryo transferred was performed under ultrasound guided. One to two day 5-6 blastocyst was transferred in CC group and two to three day 3 cleavage embryo was transferred in control group. Luteal phase support was given based on different clinician and cases.

\section{Study outcomes}

We extracted data from the medical records on patient demographic, type of protocol, stimulation parameter and the laboratory outcome. Oocyte atresia, poor quality of oocyte and failure of fertilization was a consequences of premature LH surge. The indirect method to measure the evidence of LH surge was by study on the laboratory outcome as we do not perform blood or urine LH test for patients as the blood test result would release by few days after the blood taking. The study primary outcome was on fertilization rate and the secondary outcome included oocyte retrieval rate, mature oocyte rate and top quality embryo rate. OHSS risk was studied if the number of follicle during TVOR reaching $\geq 15$. Top quality was defined by Veeck's criteria for cleavage embryo day 3 and Gardner and Schoolcraft (1999) criteria for blastocyst day 5-6 blastocyst. The study was approved by ethical committee with NMMR-18-44-39835 S1 and FF-2018-164.

\section{Statistical analysis}

Descriptive analysis would be conducted for all variable. Appropriate cut off point would be obtained based on mean \pm standard deviation (SD). Independent $\mathrm{t}$ test would be use to see the association between the demographic of the study group including age, baseline FSH level before starting treatment, total dosage and injectionof gonadotropin and total stimulation days. OR rate, mature oocyte rate, fertilization rate and top quality embryo rate were compared among the two stimulation protocol with independent $t$ test. Chi square test would be use for comparison between the 2 groups with type of infertility and the risk of developing OHSS. Binary regression is conducted to analyze the causes of infertility for the dependent variable. Statistical significant would be set when $\mathrm{p}$ value is less than 0.05 using SPSS software 22 version.

\section{RESULTS}

In 2016-2017, there were total of 532 fresh stimulated ICSI cycle conducted in my centre. Among them, $382(71.8 \%)$ cases using these two ovarian stimulation protocol. Fertilization rate was highly dependent on the quality of the oocyte and sperm, hence we decided to exclude patients with female age $>40$ years old, poor ovarian reserve $(\mathrm{FSH}>10 \mathrm{iu} / \mathrm{mL}$ or $\mathrm{AMH}<5.4 \mathrm{pmol} / \mathrm{L})$ and azoospermia patients. We included total of $235 \mathrm{pa}-$ tients with complete data that underwent first and fresh stimulated ICSI cycle (no history of failed IVF) with $\mathrm{CC}$ plus gonadotropin protocol $(\mathrm{n}=117)$ and $\mathrm{GnRH}$ antagonist protocol $(\mathrm{n}=118)$.

The demographic and hormonal characteristic of study groups was shown in Table 1. There were no signif-

Table 1. Demographic and hormonal characteristic of study groups

\begin{tabular}{|l|c|c|c|}
\hline & $\begin{array}{c}\text { CC group } \\
(\mathrm{n}=117)\end{array}$ & $\begin{array}{c}\text { GnRH Antagonist } \\
\text { group (control) } \\
(\mathrm{n}=118)\end{array}$ & P value \\
\hline Age (years)* & $34.3 \pm 3.2$ & $34.6 \pm 3.4$ & 0.497 \\
\hline $\begin{array}{l}\text { Type of infertility } \mathbb{8} \\
\text { Primary }\end{array}$ & $82(70.1 \%)$ & $92(78.0 \%)$ & 0.168 \\
Secondary & $35(29.9 \%)$ & $26(22.0 \%)$ & \\
\hline Causes of infertilityo & & & \\
Male & $22(18.8 \%)$ & $20(16.9 \%)$ & 0.711 \\
Tubal & $22(18.8 \%)$ & $14(16.9 \%)$ & 0.711 \\
PCOS & $10(8.5 \%)$ & $10(8.5 \%)$ & 0.984 \\
Endometriosis & $17(14.5 \%)$ & $18(15.3 \%)$ & 0.876 \\
Others & $15(12.8 \%)$ & $22(18.6 \%)$ & 0.220 \\
Unexplained & $31(26.5 \%)$ & $28(23.7 \%)$ & 0.625 \\
\hline $\begin{array}{l}\text { Baseline FSH } \\
\text { (miu/ml)* }\end{array}$ & $5.65 \pm 1.51$ & $5.33 \pm 1.52$ & 0.103 \\
\hline
\end{tabular}

FSH: follicle stimulating hormone

*expressed as mean $+\mathrm{SD}$ and $\mathrm{p}$ value was calculated by the student $\mathrm{t}$ test $\infty$ expresses in $\mathrm{n}(\%)$ and $\mathrm{p}$ value was calculated by binary logistic regression ( $)$ expresses in $\mathrm{n}(\%)$ and $\mathrm{p}$ value was calculated by chi square test 
Table 2. Stimulation protocol and complications

\begin{tabular}{|l|c|c|l|}
\hline & $\begin{array}{c}\text { CC group } \\
(\mathrm{n}=117)\end{array}$ & $\begin{array}{c}\text { GnRH } \\
\text { Antagonist } \\
\text { group (control) } \\
(\mathrm{n}=118)\end{array}$ & P value \\
\hline $\begin{array}{l}\text { Total Gonadotropins } \\
\text { dosage, iu }\end{array}$ & $1450.6 \pm 545.2$ & $2445.3 \pm 569.0$ & $<0.001$ \\
\hline $\begin{array}{l}\text { Total days of } \\
\text { gonadotropin } \\
\text { injection, d }\end{array}$ & $6.9 \pm 2.1$ & $11.3 \pm 1.1$ & $<0.001$ \\
\hline $\begin{array}{l}\text { Total days of } \\
\text { stimulation with } \\
\text { medication, d }\end{array}$ & $11.3 \pm 1.9$ & $11.3 \pm 1.1$ & 0.945 \\
\hline $\begin{array}{l}\text { Endometrial thickness } \\
\text { during HCG } \\
\text { triggering day, mm }\end{array}$ & $8.5 \pm 1.0$ & $9.4 \pm 1.1$ & $<0.001$ \\
\hline Risk of OHSS $\mathbb{2}$ & $15(12.8 \%)$ & $52(44.1 \%)$ & $<0.001$ \\
\hline
\end{tabular}

${ }^{\circledR}$ expresses in $n(\%)$ and $p$ value was calculated by chi square test

*expressed as mean $+\mathrm{SD}$ and $\mathrm{p}$ value was calculated by the student $\mathrm{t}$ test

icant difference among both protocol in age, type of infertility, causes of infertility and the baseline FSH level.

Total gonadotropin dosage, total days of gonadotropin injection and OHSS risk were significant difference in CC group (Table 2). The total days of ovarian stimulation among two groups was not significant difference similar with standard protocol. Our study showed significant difference of endometrial thickness among both groups $(8.5 \mathrm{~mm} \pm 1.0 \mathrm{~mm}$ VS $9.4 \mathrm{~mm} \pm$ $1.1 \mathrm{~mm}, \mathrm{p}<0.001)$.

Our primary outcome as in fertilization rate were significant difference with $\mathrm{p}$ value 0.003 . Fertilization rate for $\mathrm{CC}$ group was $73.2 \%$ and $\mathrm{GnRH}$-antagonist group was $64.2 \%$. However the secondary outcome for our study for OR rate $(78.4 \% \pm 17.6 \%$ VS $80.3 \% \pm$ $13.4 \%, \mathrm{p}=0.368)$, mature oocyte rate $(85.2 \% \pm 19.0 \%$ VS $81.7 \% \pm 16.7 \%, p=0.130)$ and top quality embryo rate $(79.4 \% \pm 24.2 \%$ VS $74.9 \% \pm 22.9 \%, p=0.178)$ were comparable among those two protocol.

\section{DISCUSSION}

$\mathrm{CC}$ is commonly used as an ovarian stimulation medication in intrauterine insemination (IUI) as the principle of management is targeting monofollicular stimulation unlike COS IVF-ICSI aiming for eight to twelve follicles in one cycle. The reason behind was not all follicles contain mature oocyte and the ultimate number of surviving embryo reaching cleavage or blastocyst stage would be lesser than the number of follicles seen during triggering day depending. Clinician would feel much comfortable getting more oocyte assuming that it is rather safe to keep the number of top quality embryo in optimum number to avoid cycle cancellation.
$\mathrm{CC}$ has been used in IVF-ICSI as minimal stimulation protocol particularly in high responder patients as these are the patients at risk of OHSS. The usage on CC in minimal stimulation has been commonly seen in patient with premature ovarian insufficiency with low anti-Mullerian hormone. Various studies have shown that natural or minimal stimulation protocol is more cost effective than $\mathrm{COS}$ as the ovarian reserved is markedly reduced. It is well known that increasing dosage of gonadotropin to maximum dose seems pointless to change the fact that only few number of primordial follicle that would be stimulated in each menstrual cycle. Unlike those normo-responsive patients in which $15-20$ primordial follicle would be stimulated in each menstrual cycle. Gonadotropin is used to stimulate these follicles in order to get reasonable number of oocytes. COS has various complications include overstimulation leading to unwanted complications such as OHSS.

Our CC group were considered as minimal stimulation protocol as gonadotropin injection was started slightly later on day 4 of cycle where the peak of FSH was about to drop on this day. On the other hand, control group using GnRH antagonist as the pituitary down regulation agents had the gonadotropin injection started from day 2 to 3 onwards. This is consistent with other study $(1-5,11,12)$ result in which the total gonadotropin dosage in ICSI cycle and total days of gonadotropin injection were significant lesser than the control group. This study protocol give various benefit to patients include less pain due to lesser subcutaneous injection of gonadotropin and acceptable cost for one IVF cycle. It is considered more user friendly particularly for those with needle phobic patients. Stimulated ICSI is costly due to expensive medications including injectable gonadotropin for ovarian stimulation, HCG or GnRH agonist trigger and prolonged luteal phase support with progesterone (intramuscular or vaginally) till 7-12 week of gestation if patient conceived. Replacing the GnRH antagonist by extending CC usage could further reduce the cost in ovarian stimulation agents as GnRH antagonist is rather costly compared to oral CC (Cetrorelix, Serono: \$83.94 USD/vial; CC: \$1.35 USD/tablet). In general, total dosage of GnRH antagonist is usually 5-6 vial per cycle (one vial $0.25 \mathrm{mg}$ ) and our total CC dosage is $1000 \mathrm{mg}$ (one tablet $50 \mathrm{mg}$ ). It was very obvious that $\mathrm{CC}$ has added benefit as cheaper compared to GnRH antagonist agent (total amount of Cetrorelix: \$419.7 USD-\$ 503.6 USD VS CC: \$27 USD). Our study has proved that it is more cost effective than conventional COS with antagonist protocol and we believed that it is suitable to be used particularly in financial constraint patients or funded hospital. This would give the opportunity to low or middle class patients to rear a genetically related child. 
As CC group was minimal stimulation protocol as mentioned earlier, the number of follicle during TVOR, number of oocyte retrieved during TVOR, number of mature oocyte MII, number of fertilized embryo and number of top quality embryo were significant lesser compared to control group (Table 3). It sounded logical to obtain this findings as both groups were using two different approach where $\mathrm{CC}$ as in minimal stimulation protocol and control group was using COS protocol. This was not the aim of our study as we wanted to show that $\mathrm{CC}$ could be used safely as in $\mathrm{GnRH}$ antagonist in preventing premature LH surge without compromising the IVF outcome. We strongly believe that to start the gonadotrophin earlier as in antagonist group from day 2 or day 3 of menses would achieve the similar number of follicles, oocyte and embryos as in the control group.

The fertilization rate is very much dependent on the quality of oocyte and sperm. The result was $73.2 \%$ VS $64.2 \%$ in which the fertilization rate in CC group was significant higher than $\mathrm{GnRH}$ antagonist group. We concluded that CC could be safely use in preventing premature LH surge as it does not affect the quality of oocyte being fertilized by sperm but even better than conventional protocol with GnRH antagonist. We have proved that extensive ovarian stimulation with excessive number of follicles would certainly affect the quality of oocyte. It was consistent with the result by Bhandari S et al (7) with fertilization rate of $76.1 \%$.

Our study results showed no significant difference in secondary outcome but the top quality embryo rate and mature oocyte rate were higher than control group $(79.4 \% \pm 24.2 \%$ VS $74.9 \% \pm 22.9 \%$ and $85.2 \% \pm 19.0 \%$ VS $81.7 \% \pm 16.7 \%$ respectively). It has clearly shown that minimal stimulation with $\mathrm{CC}$ plus gonadotropin

Table 3. IVF parameters and outcome

\begin{tabular}{|c|c|c|c|}
\hline & $\begin{array}{l}\text { CC group } \\
(\mathrm{n}=117)\end{array}$ & $\begin{array}{c}\text { GnRH } \\
\text { Antagonist } \\
\text { group } \\
\text { (control) } \\
(\mathrm{n}=118)\end{array}$ & P value \\
\hline No. follicle before TVOR & $8.3 \pm 4.7$ & $14.8 \pm 8.5$ & $<0.001$ \\
\hline No. oocyte retrieved & $6.4 \pm 3.9$ & $11.8 \pm 6.7$ & $<0.001$ \\
\hline Ooctye retrieval rate, $\%$ & $78.4 \pm 17.6$ & $80.3 \pm 13.4$ & 0.368 \\
\hline No. of mature oocyte MII & $5.3 \pm 3.3$ & $9.4 \pm 5.2$ & $<0.001$ \\
\hline Mature oocyte rate, $\%$ & $85.2 \pm 19.0$ & $81.7+16.7$ & 0.130 \\
\hline No. fertilized embryo & $3.6 \pm 2.3$ & $5.8 \pm 3.8$ & $<0.001$ \\
\hline Fertilization rate, $\%$ & $73.2 \pm 24.0$ & $64.2 \pm 21.7$ & 0.003 \\
\hline No. top quality embryo & $2.6 \pm 1.6$ & $4.1 \pm 2.7$ & $<0.001$ \\
\hline Top quality embryo rate, $\%$ & $79.4 \pm 24.2$ & $74.9 \pm 22.9$ & 0.178 \\
\hline
\end{tabular}

All expresses in mean $\pm \mathrm{SD}$ and $\mathrm{p}$ value was calculated by student $\mathrm{t}$ test without adding GnRH antagonist is effective in preventing LH surge. The only benefit of maximal ovarian stimulation is to obtain more number of embryos which most of the clinician believe that by increasing the number of embryo could increase the pregnancy rate particularly cumulative pregnancy per cycle. But we would like to against this statement in why need to get more but moderate quality of embryo. Isn't it redundant by doing so with added complications and risk to our patients?

Medroxyprogesterone has been used in preventing premature LH surge (13) by Kuang et al (13) however it does not has added role as in CC for ovarian stimulation and it does not has an extra benefit as CC in reducing the total dosage of gonadotropin and total days of stimulation (CC has positive effect on ovarian follicle development). This would provide an advantage in resources restricted ART centre (6) by providing an affordable assisted reproductive technique to patients $(11,12,14,15)$. Gonadotropin agents are potent ovarian stimulation compared to $\mathrm{CC}$ and close monitoring every 2 to 3 days is needed during the ovarian stimulation to allow clinician to adjust the dosage of gonadotropin depending on the response of the ovarian stimulation. As $\mathrm{CC}$ has added advantage in reducing the total days of gonadotropin injection in $\mathrm{CC}$ group, minimal stimulation protocol requires fewer clinic visits for monitoring $(12,14)$ compared to conventional GnRH antagonist protocol. Frequent clinic visits to clinic would add burden to patients in applying leave and indirectly affect their performance in work.

In recent years, we moved toward single day 5 top quality embryo transfer as this could reduce the likelihood of multiple birth and increase the chances of pregnancy rate. The transitional of practice in embryo transfer from cleavage embryo to day 5 blastocyst was adopted by most of the IVF centre in decadesto increase the implantation rate as clinician believe that only the top quality embryo could survive till day 5 . The number of embryos left in day 5 compared to day 3 would definitely lesser possible facing the problem of cycle cancellation. This would explain the reason of reduction in the number of top quality day 5 blastocyst in CC group (mean $\pm \mathrm{SD}: 2.6 \pm 1.6$ ) compared to day 3 embryo in $\mathrm{GnRH}$ antagonist group (mean $\pm \mathrm{SD} 4.1 \pm 2.7$ ).

Conventional $\mathrm{COH}$ may offer a higher chance for embryo transfer with more surplus embryo compared to mild stimulation protocol (16). Cumulative pregnancy per one IVF cycle would be higher in conventional $\mathrm{COH}$ which make minimal stimulation less popular (5) and it is still a debatable issue regarding the long term cost effectiveness $(1,17)$ as patient need to restart a new stimulated IVF cycle if no surplus embryos left for the embryo transfer which is commonly seen in mild stimulation protocol. 
Endometrial thickness on the day of HCG administration is prognostic of fecundity and continuing of pregnancy in cycle of ovulation induction and Richard et al, 1993 has proved that CC plus gonadotropin would affect the EM thickness (18) many years ago which is consistent with my study results. However with the advancement of vitrification system, freeze-thaw embryo transfer is the best option to solve this problem and in future we are slowly moved towards freeze all as reported to achieve higher success rate (19).

OHSS is a common complications following ovarian stimulation particularly when the number of follicle is more than $15>$ during TVOR. Despite knowing that OHSS would not affect the pregnancy but Barbara et al has proved that it is associated with adverse pregnancy outcome (20). The OHSS risk for our CC group was significant low (12.8\% VS 44.1\%) which is safer to the over-respondent patients. We shall provide the best care and plan to patients without causing more harm to patients. The limitation of our study is retrospective and present of confounding factors such as various causes of infertility, different usage of HCG triggering agent and different type of gonadotropin that would affect the outcome. Our study is still ongoing on pregnancy outcome such as clinical pregnancy rate, ongoing pregnancy rate, live birth rate and cumulative pregnancy rate as most of the clinician concerned about. In future, we shall consider the usage of Letrozole (aromatase inhibitor) instead of CC that would not affect the endometrial thickness allowing fresh embryo transfer $(21,22)$.

Our study showed that by extending $\mathrm{CC}$ to 10 days without adding antagonist is safe without antagonist agent. In Herndon et al (11) study, no GnRH antagonist protocol and hormonal blood test was taken during COS IVF-ICSI. Their results has showed the fertilization rate in $\mathrm{CC}$ plus gonadotrophin (flare protocol) has comparable result $(\mathrm{p}=0.37)$ as other protocol like $\mathrm{CC} /$ Letrozole alone, sequential protocol and gonadotrophin alone. It is feasible not to add GnRH antagonist agent if extending $\mathrm{CC}$ from 5 to 10 days as an agent to prevent premature ovarian surge.

\section{CONCLUSION}

It has always being a challenge for clinician using gonadotrophin stimulation in the occurrence of premature LH surge. The incidence of premature LH surge varies depending on different studies. Luteinization before ovarian follicle maturation give negative impact on the quality of oocyte and embryos.

Although the use of GnRH antagonist co-administration is advisable for mild stimulation to prevent $\mathrm{LH}$ surge but our study examine that not adding GnRH antagonist in mild stimulation protocol is viable option with comparable outcome with conventional $\mathrm{COH}$
-ICSI consistent with other studies $(5,7,23)$. Minimal stimulation protocol with $\mathrm{CC}$ and gonadotropin may be the answer to many infertile couples in need of IVF and yet having financial situation deterring them in attempting IVF treatment. It may be a suitable protocol for over-respondent patients knowing the fact that the quality of the oocytes is inversely with the number of oocytes obtaining from transvaginal oocyte retrieval.

In conclusion, IVF cycle is a burdensome process and we as a clinician should provide a friendly $\mathrm{COH}$ protocol to our patients and the safety of the patients should be prioritized avoiding or minimizing the complications. We should rethink the aim of "successful IVF" by helping patient to conceive or to complete the family. Why need more and extensive ovarian stimulation like conventional GnRH antagonist protocol by risking the patients to unwanted complications? $\mathrm{CC}$ is effective in COH-ICSI particularly in low economy country and did not have negative influence on the treatment outcome. Management for ART protocol should always be individualized (24) as every patients are different.
Abbreviations
ICSI - Intracytoplasmic sperm injection
CC - Clomiphene citrate
OI - Ovulation induction
GnRH - Gonadotropin releasing hormone
FSH - Follicular stimulating hormone
LH - Luteinizing hormone
OHSS - Ovarian hyperstimulation syndrome
OR - Oocyte retrieval
MII - Metaphase II
COS - Controlled ovarian stimulation
FET - Frozen embryo transfer

\section{Acknowledgment}

Dr Kurubaran Ganasegeran, Clinical research centre, Seberang Jaya Hospital, Ministry of Health Malaysia, Penang

\section{DECLARATION OF INTEREST}

The investigators declare they have no conflict of interest.

\section{NAME AND ADDRESS OF SPONSOR}

University Kebangsaan Malaysia (UKM), Malaysia

\section{STUDY SITE}

Reproductive Medicine Centre

Department of Obstetrics and Gynaecology

University Kebangsaan Malaysia 


\section{DECLARATION OF INTEREST}

The autors declare that there are no conflicts of interests.

\section{Licensing}

This work is licensed under a Creative Commons Attribution 4.0 International (CC BY 4.0) License.

Sažetak

\title{
STUDIJA EFIKASNOSTI KLOMIFEN CITRATA U POREĐENJU SA GnRH ANTAGONISTIMA U PREVENCIJI SKOKA LH MEĐU PACIJENTKINJAMA KOJE SU NA STIMULACIJI JAJNIKA U PROCESU IVF-ICSI
}

\author{
Shiuan Yee Tan, ${ }^{1}$ Salleha Khalid, ${ }^{2}$ Mohamad Azrai Abu, ${ }^{3}$ \\ Abdul Kadir Abdul Karim, ${ }^{3}$ Mohd Hashim Omar ${ }^{3}$ \\ ${ }^{1}$ Seberang Jaya Hospital, Ministry of Health, Malaysia \\ ${ }^{2}$ Faculty medicine and health sciences, University Sains Islam Malaysia (USIM), Malaysia \\ ${ }^{3}$ UKM Reproductive centre, Department of obstetrics and gynecology, University Kebangsaan Malaysia, Malaysia
}

Cilj: Cilj ove studije bio je da se utvrdi efikasnost klomifen citrata (CC) u prevenciji skoka luteinizirajućeg hormona (LH) bez dodavanja antagonista gonadotropnog oslobađajućeg hormona (GnRH) i GnRH agoniste u prethodno stimulisanim ćelijama ICSI ciklusom, koristeći zrelost oocita i kvalitet embriona kao ishod. Dizajn studije: retrospektivna kohortna studija Lokacija: Klinika za fertilitet pri Univerzitetskoj bolnici Kebangsaan Malezija. Pacijenti: Ukupno 235 pacijenata je bilo uključeno u studiju, starosne dobi 18-40 godina, koji su stimulisani ICSI ciklusom pri čemu je u jednoj grupi korišćen klomifen citrat $\mathrm{u}$ kombinaciji sa gonadotropinom $(n=117)$, dok je u drugoj korišćen GnRH antagonista u kombinaciji a gonadotropinom $(n=118)$. Intervencija: Upoređivanje dva različita protokola stimulaciju jajnika. Varijable: socio-ekonomska demografija, odgovor na stimulaciju ovarijuma i laboratorijske analize. Stopa fertilizacije kao primarni ishod, a kao sekundarni ishod uključeni su stopa oocitnog povlačenja, stopa zrelosti oocita i stopa kvaliteta embriona. Rezultati: Nije bilo statističke značajnosti u poređenju hormonskih i demografskih karakteristika među grupama. Kada se posmatra primarni ishod, odnosno stopa fertilizacije, primećena je statistička značajnost i p vrednost je 0,003 ;

\section{REFERENCES}

1. Orvieto R, Vanni VS, Gleicher N. The myths surrounding mild stimulation in vitro fertilization (IVF). Reprod Biol Endocrinol. 2017; 15(1): 48.

2. Nargund G, Fauser B, Macklon N, Ombelet W, Nygren $\mathrm{K}$, Frydman R et al. The ISMAAR proposal on terminology for ovarian stimulation for IVF. Hum Reprod. 2007; 22(11): 2801-4.

3. Verberg M, Macklon NS, Nargund G, Frydman R, Devroey P, Broekmans F, et al. Mild ovarian stimulation for IVF. Hum reprod update. 2009; 15(1): 13-29.

4. Hammoud AO, Gibson M. Minimal stimulation IVF Biennial Review of Infertility: Springer; 2011. p. 11-8.
$73,2 \%$ CC grupe i 64,2\% GnRH antagonist grupe. Sekundarni ishod stope $(78,4 \% \pm 17,6 \%$ vs $80,3 \% \pm 13,4 \%$, $\mathrm{p}=0,368)$, stopa zrelosti oocita $(85,2 \% \pm 19,0 \%$ vs $81,7 \% \pm 1,7 \%, \mathrm{p}=0,130)$ i stopa kvaliteta embriona $(79,4 \% \pm 24,2 \%$ vs $74,9 \% \pm 22,9 \%, p=0,178)$ bile su upoređivane između grupa. Pokazana je statistička značajnost između debljine endometrijuma na dan okidanja $i$ OHSS rizik među grupama $(8,5 \mathrm{~mm} \pm 1,0 \mathrm{~mm}$ vs $9,4 \mathrm{~mm}$ $\pm 1,1 \mathrm{~mm}, \mathrm{p}<0,001 \mathrm{i} 12,8 \%$ vs $44,1 \%$ respektivno). Diskusija: Protokol minimalne stimulacije sa CC i gonadotropinom može biti rešenje za većinu parova koji su suočeni sa problemom neplodnosti i kojima se savetuje IVF, a koji nisu u situaciji da to finansiraju. GnRH antagonist može da zameni CC, produžaanjem još 10 dana jer ovako unapređen protokol pokazuje bolji ishod i komparabilni sekundarni ishod sa manjim OHSS rizikom. Zna se da CC smanjuje debljinu endometrijuma. S toga, može nepovoljno uticati na impantaciju embriona. Međutim, imajući u vidu unapređenje vitrifikacionog Sistema i veći broj uspešnih embriotransfera širom sveta, može se reći da je i ova metoda odlično rešenje neplodnosti.

Ključne reči: klomifen citrate, minimalna stimulacija, GnRh antagonisti, prematurni LH skok, niska cena IVF.

5. Fauser BC, Nargund G, Andersen AN, Norman R, Tarlatzis B, Boivin J, et al. Mild ovarian stimulation for IVF: 10 years later. Hum reprod. 2010; 25(11): 2678-84.

6. Matsaseng T, Kruger T, Zunza M. A simple method of extended 8 days course of clomiphene citrate versus 5 days course in an attempt to suppress premature luteinizing hormone surge in an assisted reproductive technology program: A randomized controlled trial. IVF Lite. 2016; 3(1): 11.

7. Bhandari S, Ganguly I, Chittawar PB, Agarwal P, Singh A, Gupta N. Use of clomiphene to prevent premature luteinizing hormone surge during controlled ovarian hyper stimulation. International Journal of Reproduction, Contraception, Obstetrics and Gynecology. 2017; 5(6): 1944-8. 
8. Engel J, Ludwig M, Felberbaum R, Albano C, Devroey P, Diedrich K. Use of cetrorelix in combination with clomiphene citrate and gonadotrophins: a suitable approach to "friendly IVF"? Hum Reprod. 2002; 17(8): 2022-6.

9. Al-Inany H, Azab H, El-Khayat W, Nada A, El-Khat$\tan$ E, Abou-Setta AM. The effectiveness of clomiphene citrate in LH surge suppression in women undergoing IUI: a randomized controlled trial. Fertil Steril. 2010; 94(6): 2167-71.

10. von Wolff M, Nitzschke M, Stute P, Bitterlich N, Rohner S. Low-dosage clomiphene reduces premature ovulation rates and increases transfer rates in natural-cycle IVF. Reprod biomed online. 2014; 29(2): 209-15.

11. Herndon CN, Anaya Y, Noel M, Cakmak H, Cedars MI. Outcomes from a university-based low-cost in vitro fertilization program providing access to care for a low-resource socioculturally diverse urban community. Fertil Steril. 2017; 108(4): 642-9.

12. Polinder S, Heijnen E, Macklon N, Habbema J, Fauser B, Eijkemans M. Cost-effectiveness of a mild compared with a standard strategy for IVF: a randomized comparison using cumulative term live birth as the primary endpoint. Hum Reprod. 2007; 23(2): 316-23.

13. Kuang Y, Chen Q, Fu Y, Wang Y, Hong Q, Lyu Q, et al. Medroxyprogesterone acetate is an effective oral alternative for preventing premature luteinizing hormone surges in women undergoing controlled ovarian hyperstimulation for in vitro fertilization. Fertility and sterility. 2015; 104(1): 62-70. e3.

14. Dixon S, Faghih Nasiri F, Ledger W, Lenton E, Duenas A, Sutcliffe P, et al. Cost effectiveness analysis of different embryo transfer strategies in England. BJOG: An International Journal of Obstetrics and Gynaecology. 2008; 115(6): 758-66.

15. Vayena E, Rowe PJ, Peterson HB. Assisted reproductive technology in developing countries: why should we care? Elsevier; 2002.

16. Verberg M, Eijkemans M, Macklon N, Heijnen E, Baa$\mathrm{rt}$ E, Hohmann F, et al. The clinical significance of the retrieval of a low number of oocytes following mild ovarian stimulation for IVF: a meta-analysis. Hum reprod update. 2009; 15(1): 5-12.

17. Mansour RT, Aboulghar MA, Serour GI, Al Inany HG, Fahmy I, Amin Y. The use of clomiphene citrate/human menopausal gonadotrophins in conjunction with $\mathrm{GnRH}$ antagonist in an IVF/ICSI program is not a cost effective protocol. Acta obstet gynecol Scand. 2003; 82(1): 48-52.

18. Dickey RP, Olar TT, Taylor SN, Curole DN, Matulich EM. Relationship of endometrial thickness and pattern to fecundity in ovulation induction cycles: effect of clomiphene citrate alone and with human menopausal gonadotropin. Fertil steril. 1993; 59(4): 756-60.

19. Roque M, Lattes K, Serra S, SolB I, Geber S, Carreras $\mathrm{R}$, et al. Fresh embryo transfer versus frozen embryo transfer in in vitro fertilization cycles: a systematic review and meta-analysis. Fertil steril. 2013; 99(1): 156-62.

20. Luke B, Brown MB, Morbeck DE, Hudson SB, Coddington CC, Stern JE. Factors associated with ovarian hyperstimulation syndrome (OHSS) and its effect on assisted reproductive technology (ART) treatment and outcome. Fertil steril. 2010; 94(4): 1399-404.

21. Haas J, Bassil R, Meriano J, Samara N, Barzilay E, Gonen N, et al. Does daily co-administration of letrozole and gonadotropins during ovarian stimulation improve IVF outcome? Reprod Biol Endocrinol. 2017; 15(1): 70.

22. Fisher SA, Reid RL, Van Vugt DA, Casper RF. A randomized double-blind comparison of the effects of clomiphene citrate and the aromatase inhibitor letrozole on ovulatory function in normal women. Fertil steril. 2002; 78(2): 280-5.

23. Fernández-Shaw S, Esturo NP, Duque RC, Mallol IP. Mild IVF using GnRH agonist long protocol is possible: Comparing stimulations with $100 \mathrm{IU}$ vs. $150 \mathrm{IU}$ recombinant FSH as starting dose. J assist reprod genet. 2009; 26(2-3): 75-82.

24. Penzias A. Improving results with assisted reproductive technologies: individualized patient-tailored strategies for ovulation induction. Reprod biomed online. 2011; 22:S83-6.

\section{Correspondence to / Autor za korespondenciju}

Shiuan Yee Tan

Seberang Jaya Hospital, Ministry of Health Malaysia

Phone number: +60125832216

Fax number: +6043322624

Mailing address: 14, Jalan Bagan Lalang 1, Taman Bagan Lalang,

13400 Buttwerworh, Penang, Malaysia

Email address: tshiuan@yahoo.com, sytan1001@mail.com 